\title{
The 2007 Caribbean Community Port-of-Spain Declaration on noncommunicable diseases: an overview of a multidisciplinary evaluation
}

\author{
T. Alafia Samuels ${ }^{1}$ and Nigel Unwin ${ }^{1}$
}

Suggested citation

Samuels TA, Unwin N. The 2007 Caribbean Community Port-of-Spain Declaration on noncommunicable diseases: an overview of a multidisciplinary evaluation. Rev Panam Salud Publica. 2018;42:e193. https://doi.org/10.26633/RPSP.2018.193

ABSTRACT Objectives. Noncommunicable diseases (NCDs) are a threat to social and economic development, including in the Caribbean. In 2007 the Caribbean Community (CARICOM) held the world's firstever summit of heads of government on NCD prevention and control and issued the landmark Declaration of Port-of-Spain: Uniting to Stop the Epidemic of Chronic NCDs. The objectives of this paper are to provide an overview of a formal evaluation of the Declaration and to highlight key findings that could inform further implementation of the Declaration's 15 mandates.

Methods. The evaluation's six research objectives were decided through stakeholder engagement and assessed by concurrent quantitative and qualitative research methods, using the following four themes: 1) trends in risk factors, morbidity, and mortality; 2) national and Caribbean-wide policy responses, and factors associated with policy successes and difficulties; 3) the international impact of the Declaration; and 4) the potential for raising revenue from tobacco and alcohol taxation in order to support NCD prevention and control.

Results. There are marked disparities in NCD mortality and trends among the 20 CARICOM member countries and territories. No CARICOM member had fully implemented all of the Declaration's 15 mandates (which were monitored by 26 indicators), with 10 CARICOM members implementing fewer than half of the indicators, and with most members lacking a well-functioning multisectoral NCD Commission. Larger CARICOM members tended to have higher levels of implementation than did smaller members. Mandates that received active support from regional institutions tended to be better implemented by the CARICOM members than did mandates that lacked that kind of support. Feasible national tobacco and alcohol tax increases could more than cover the cost of implementing the World Health Organization NCD "best buy" interventions in the CARICOM member countries and territories.

Conclusions. Priorities for further implementation of the mandates from the Port-of-Spain Declaration include establishing throughout the CARICOM member countries and territories fully functioning national bodies to support multisectoral action for NCD prevention; greater regional support in policy development and implementation for smaller countries; and greater targeted use of taxes on tobacco and alcohol to support NCD control and prevention.

Keywords Noncommunicable diseases; preventive medicine; health policy; research design; diagnosis of health situation; Caribbean Region.

\footnotetext{
George Alleyne Chronic Disease Research Centre, University of the West Indies, Bridgetown, Barbados. Send correspondence to T. Alafia Samuels, at alafia.samuels@cavehill.uwi.edu or alafiasam@gmail.com
}

The epidemic of chronic noncommunicable diseases (NCDs) in the Caribbean is worse than in any other region of the Americas, with premature mortality (for those 30-69 years old) being double the rates in North America (1, 2). NCDs are clearly a threat to Caribbean social and economic development (3). 
Underlying the high rates of premature NCD mortality in the Caribbean are high levels of risk factors, particularly unhealthy diet and physical inactivity, which lead to high rates of obesity, diabetes, and hypertension $(1,2,4-6)$. Tobacco smoking and excessive alcohol consumption, particularly in men, are additional drivers of the epidemic $(1,4,5)$.

The Caribbean Community (CARICOM) is a political grouping of 20 small island developing states (https:/ / caricom.org/about-caricom/who-weare/our-governance/members-andassociate-members/). The 20 consist of 15 full members and 5 associate members, with all the 5 associate members being overseas territories of the United Kingdom. Of the 15 full members, 14 are independent states; the 15th is Montserrat, which is a full member of CARICOM despite being an overseas territory of the United Kingdom. Most of the 20 are English-speaking members of the Commonwealth, along with French- and Creole-speaking Haiti and Dutch-speaking Suriname. For historical reasons, the mainland countries of Belize, Guyana, and Suriname are full members of CARICOM.

There has been a long tradition of cooperation in health in CARICOM, resulting, for example, in the region being the first in the world to eliminate measles $(7,8)$.

The Caribbean has undergone the epidemiological and demographic transition (9-11), and it has the highest rates of premature cardiovascular mortality in the Region of the Americas $(12,13)$.

Advocacy by Sir George Alleyne and others on the health, social, and economic impacts of NCDs promoted "upstream" multisectoral interventions to address the underlying determinants of the behavioral risk factors (10). In response, in 2007, CARICOM held the world's first-ever summit of heads of government on NCD prevention and control and issued the landmark Declaration of Port-of-Spain: Uniting to Stop the Epidemic of Chronic NCDs (14). The Declaration contained 15 actionable mandates.

CARICOM and the Pan American Health Organization (PAHO) were responsible for monitoring and evaluating the Declaration. Regular, annual monitoring of CARICOM members' responses has been conducted through the reporting on 26 indicators from the 15 mandates (Table 1). The reporting is done annually by NCD focal points in the ministries of health, reviewed by each country's Chief Medical Officer (CMO) in the ministry of health, and presented to the annual caucus of CARICOM health ministers. A monitoring reporting grid was developed in 2008 and revised in 2010 (15).

Given the central role of the 2007 Portof-Spain Declaration in shaping NCD policy and programs in the Caribbean and beyond, it was important to more thoroughly evaluate the degree of implementation of the Declaration's mandates. To this end, in 2013, the University of the West Indies drew up detailed plans for an evaluation. In March 2014, the Canadian International Development Research Centre (IDRC) approved funding for a three-year evaluation and dissemination project.

The aim of this paper is to provide an overview of the evaluation's objectives and the methods used, and to summarize some of its core findings. Other papers in this supplement of this journal present detailed analyses from several of the evaluation's specific objectives (Box 1) (16-25).

\section{METHODS}

\section{Evaluation objectives}

The overarching objective of the evaluation was to assess seven years on, the implementation of the 2007 Port-of-Spain Declaration in order to learn lessons that will support and accelerate its further implementation and will inform the attainment of the commitments of United Nations' 2011 High-level Meeting of the General Assembly on the Prevention and Control of Non-communicable Diseases. This overarching objective was elaborated into eight detailed project objectives (Box 1). The first six of these are research objectives, which essentially cover the following themes: 1) trends in risk factors, morbidity, and mortality; 2) national and Caribbean-wide policy responses, and factors associated with policy successes and difficulties; 3 ) the international impact of the Declaration; and 4) the potential for raising revenue from tobacco and alcohol taxation in order to support NCD prevention and control. Objectives 7 and 8 are to disseminate and use the research findings to strengthen the multisectoral response in the Caribbean towards the prevention and control of the NCD epidemic.

\section{Evaluation leadership and partners}

The evaluation was led and coordinated by the Faculty of Medical Sciences Public Health Group and the George Alleyne Chronic Disease Research Centre at the University of the West Indies (UWI), in Barbados. Partners who contributed to meeting one or more of the research objectives included: the HEU Centre for Health Economics and the Institute of International Relations, UWI St. Augustine campus (Trinidad and Tobago); Department of Community Health and Psychiatry, UWI Mona campus (Jamaica); the Caribbean Public Health Agency (CARPHA); the Global Health Diplomacy Programme at the University of Toronto; and the Pan American Health Organization Eastern Caribbean Office. The key partner in the dissemination phase of the project was the Healthy Caribbean Coalition, which provided support for the development of the project website, policy briefs, videos, and other associated materials.

All partners were members of the project steering group, which met monthly throughout the lifetime of project. They were supported by a project advisory committee, which included experienced international leaders in public health. The advisory committee provided feedback on draft protocols for the specific objectives. (All the partners and advisory committee members are listed in the acknowledgments section of this article.)

\section{Overview of the research methods}

There are eight research objectives. Objectives 1 to 6 are research objectives; Objectives 7 and 8 are to disseminate and use the research findings.

Detailed protocols were developed for each of the six research objectives, using as appropriate a mixture of quantitative and qualitative data collection and analytical methods. The detailed protocols can be found as part of the evaluation's main technical report (26), which is available on the project's website (https://onecaribbeanhealth.org/ wp-content/uploads/2018/01/ POSDEVAL_The-Investigators-report_ FINAL.pdf). In addition, several papers published in this supplement issue of the 
TABLE 1. Caribbean Community (CARICOM) 2007 Port-of-Spain Declaration mandates and related national and regional indicators

\begin{tabular}{l} 
Declaration mandate \\
\hline 1. Our full support for the initiatives and mechanisms aimed at strengthening regional health institutions, to \\
provide critical leadership required for implementing our agreed strategies for the reduction of the burden \\
of Chronic, Non-Communicable Diseases as a central priority of the Caribbean Cooperation in Health \\
Initiative Phase III (CCH III), being coordinated by the CARICOM Secretariat, with able support from \\
the Pan American Health Organization/World Health Organization (PAHO/WHO) and other relevant \\
partners
\end{tabular}

2. That we strongly encourage the establishment of National Commissions on NCDs or analogous bodies to plan and coordinate the comprehensive prevention and control of chronic NCDs

3. Our commitment to pursue immediately a legislative agenda for passage of the legal provisions related to the International Framework Convention on Tobacco Control; urge its immediate ratification in all States which have not already done so and support the immediate enactment of legislation to limit or eliminate smoking in public places, ban the sale, advertising and promotion of tobacco products to children, insist on effective warning labels and introduce such fiscal measures as will reduce accessibility of tobacco

4. That public revenue derived from tobacco, alcohol or other such products should be employed, inter alia for preventing chronic NCDs, promoting health and supporting the work of the Commissions

5. That our Ministries of Health, in collaboration with other sectors, will establish by mid-2008 comprehensive plans for the screening and management of chronic diseases and risk factors so that by $2012,80 \%$ of people with NCDs would receive quality care and have access to preventive education based on regional guidelines

6. That we will mandate the re-introduction of physical education in our schools where necessary, provide incentives and resources to effect this policy and ensure that our education sectors promote programmes aimed at providing healthy school meals and promoting healthy eating

7. Our endorsement of the efforts of the Caribbean Food and Nutrition Institute (CFNI), Caribbean Agricultural Research and Development Institute (CARDI) and the regional inter-governmental agencies to enhance food security and our strong support for the elimination of trans-fats from the diet of our citizens, using the CFNI as a focal point for providing guidance and public education designed toward this end

8. Our support for the efforts of the Caribbean Regional Negotiating Machinery (CRNM) to pursue fair trade policies in all international trade negotiations thereby promoting greater use of indigenous agricultural products and foods by our populations and reducing the negative effects of globalisation on our food supply

9. Our support for mandating the labelling of foods or such measures as are necessary to indicate their nutritional content through the establishment of the appropriate regional capability

10. That we will promote policies and actions aimed at increasing physical activity in the entire population, e.g. at work sites, through sport, especially mass activities, as vehicles for improving the health of the population and conflict resolution and in this context we commit to increasing adequate public facilities such as parks and other recreational spaces to encourage physical activity by the widest cross-section of our citizens

11. Our commitment to take account of the gender dimension in all our programmes aimed at the prevention and control of NCDs

12. That we will provide incentives for comprehensive public education programmes in support of wellness, healthy life-style changes, improved self-management of NCDs and embrace the role of the media as a responsible partner in all our efforts to prevent and control NCDs

13. That we will establish, as a matter of urgency, the programmes necessary for research and surveillance of the risk factors for NCDs with the support of our Universities and the Caribbean Epidemiology Centre/Pan American Health Organization (CAREC/PAHO)

14. Our continuing support for CARICOM and PAHO as the joint Secretariat for the Caribbean Cooperation in Health $(\mathrm{CCH})$ Initiative to be the entity responsible for revision of the regional plan for the prevention and control of NCDs, and the monitoring and evaluation of this Declaration

15. We hereby declare the second Saturday in September "Caribbean Wellness Day," in commemoration of this landmark Summit.

Source: Indicators created by author T.A. Samuels and validated by country NCD focal points.

${ }^{a}$ The national indicators are numbered, and the regional indicators are unnumbered. The abbreviations used in the Indicator(s) column are: FCTC = Framework Convention on Tobacco Control; NCD = noncommunicable disease; $\mathrm{PHC}=$ primary health care.
1) NCD plan

2) NCD summit convened

3) Multi-sectoral NCD Commission appointed and functional

4) FCTC ratified

5) Tobacco taxes $>50 \%$ sale price

6) Smoke-free indoor public places

7) Advertising, promotion \& sponsorship bans

8) NCD budget

9) Chronic Care Model/NCD treatment protocols in $\geq$ $50 \%$ PHC facilities

10) Quality of care in cardio-vascular disease or diabetes demonstration project

11) Mandatory physical activity in all grades in schools

12) Policy \& standards promoting healthy eating in schools implemented

13) Multi-sector food \& nutrition plan implemented

14) Trans fat-free food supply

15) Trade agreements utilized to meet national food security \& health goals

16) Mandatory labeling of packaged foods for nutrition content

17) Mandatory provision for physical activity in new housing developments

18) Ongoing, mass physical activity or new public physical activity spaces

19) $\geq 50 \%$ of public and private institutions with physical activity and healthy eating programmes

Regional action:

- Gender considerations are included in surveillance and analyses

20) NCD communications plan

$21) \geq 30$ days per year media broadcasts on NCD control (risk factors and treatment)

Surveillance:

22) STEPS or equivalent survey

23) Minimum Data Set reporting

24) Global Youth Tobacco Survey

25) Global School Health Survey

Regional actions:

- Updated Regional NCD plan

- Monitoring grid of CARICOM 2007 Port-of-Spain Declaration mandates completed annually

- Evaluation of CARICOM 2007 Port-of-Spain Declaration mandates

26) Caribbean Wellness Day multi-sectoral, multi-focal celebrations 
BOX 1. The eight objectives of the 2014 evaluation of the Caribbean Community's 2007 Declaration of Port-of-Spain: Uniting to Stop the Epidemic of Chronic NCDs, and the papers published in this supplement of this journal addressing each objective ${ }^{a}$

\section{A. To add to knowledge on the implementation of the Port-of-Spain Declaration within CARICOM members by:}

1. Determining the extent to which the 15 mandates (monitored by 26 indicators) in the Port-of-Spain Declaration are reported to have been implemented and the national and other characteristics associated with high levels of implementation within the 20 CARICOM countries and territories Paper: Validating the self-reported annual monitoring grid for the 2007 Caribbean Community Declaration of Port-of-Spain on noncommunicable diseases, by Samuels et al. (16)

2. Describing, within the limitations of currently available data, trends in NCD mortality and risk factors from the year 2000 to 2013 , in the 20 CARICOM countries and territories

Paper: Premature mortality from cardiovascular disease and diabetes in the Caribbean and associations with health care expenditure, 2001-2011, by Razavi et al. (17)

Paper: An updated systematic review and meta-analysis on the social determinants of diabetes and related risk factors in the Caribbean, by Guariguata et al. (18)

3. Undertaking in-depth case studies within 7 countries and territories in order to determine:

a. The agreement between reported implementation of the mandates and substantive change (effective implementation)

b. The degree of use of multisectoral approaches including the engagement of civil society, the private sector and Government ministries and agencies in addition to the Ministry of Health

c. Factors associated with success and those associated with difficulties in achieving (a) and (b), including the political impact nationally

d. What evidence exists on the impact of the implementation on risk factors and health outcomes

Paper: Evaluating policy responses to noncommunicable diseases in seven Caribbean countries: challenges to addressing unhealthy diets and physical inactivity, by Murphy et al. (19)

4. Undertaking in-depth analyses of the success of policy development and implementation on the following selected major themes:

a. Documenting tobacco control measures within all CARICOM countries and investigating factors associated with their successful implementation

b. Estimating the potential for revenue generation for NCD prevention and control from taxes on tobacco and alcohol

Paper: The potential for using alcohol and tobacco taxes to fund prevention and control of noncommunicable diseases in Caribbean Community, by La Foucade et al. (20)

c. Undertaking an evaluation of the development, implementation, and potential impact of Caribbean Wellness Day.

Paper: Caribbean Wellness Day: promoting a region-wide day of action, by Bartholomew et al. (21)

B. To add to knowledge on the regional and international impact of the Port-of-Spain Declaration by:

5. Determining the degree to which regional and international bodies have met their POS NCD Declaration mandates;

6. Assessing the impact of the POS NCD Declaration regionally and internationally, including its role in instigating and shaping the UNHLM. Paper: Regional and global impacts of the 2007 Port-of-Spain Declaration on noncommunicable diseases, by Kirton et al. (22)

\section{To build capacity by:}

7. Using the lessons learnt from this evaluation to detail an action plan and implementation strategy that:

a. Fills gaps identified in the implementation of the POS NCD Declaration

Paper: The Community Food and Health Project. Health and other impacts of community food production in Small Island Developing States: a systematic scoping review, by Haynes et al. (23)

b. Takes account of multisectorality and opposed interests

Paper: Regulatory measures to fight obesity in Small Island Developing States of the Caribbean and Pacific, by Foster et al. (24)

c. Improves upon the monitoring of POS NCD mandates, monitors the WHO NCD targets, and includes the development of an indicator of investment in prevention and health promotion.

\section{To communicate this knowledge to appropriate audiences by:}

8. Disseminating the lessons learnt from this evaluation nationally and regionally to enhance implementation of POS NCD Declaration and globally to inform the attainment of commitments from the UNHLM on NCDs.

Paper: Communication strategy to disseminate the results of the evaluation of the Port-of-Spain declaration (POSDEVAL) across multiple audiences in the Caribbean, by Greaves et al. (25)

Source: Port of Spain evaluation research group.

a The abbreviations used in Box 1 are: CARICOM = Caribbean Community; NCD = noncommunicable disease; POS = Port-of-Spain; UNHLM = United Nations High-level Meeting of the General Assembly on the Prevention and Control of Non-communicable Diseases; WHO = World Health Organization.

journal describe findings from the research objectives, and provide details on the relevant methodologies; these papers are listed under the relevant objectives in Box 1.

The methods for each of the six research objectives (as described in Box 1) are summarized briefly below.
For Objective 1: Use of routinely available data on national characteristics, such as population size, per capita income, educational attainment, and female participation in the work force and representation in parliament, as potential predictors of the policy response as assessed by the monitoring grid.
For Objective 2: New analyses of routinely available data sources, including trends and disparities in NCD mortality using the World Health Organization (WHO) Mortality Database and United Nations (UN) population data. This was only possible for those countries that have provided data to the WHO Mortality 
Database and for those with populations over 90000 (as population estimates for smaller countries (including 8 of the 20 CARICOM members) are not available from the United Nations Development Program). New systematic reviews and meta-analyses were also undertaken as part of meeting this objective.

For Objective 3: In-depth, semistructured interviews with a broad range of stakeholders in seven countries.

For Objective 4(a): Data collected from countries and territories using the Framework Convention on Tobacco Control monitoring protocol. This protocol was adapted for use in the CARICOM territories that are overseas territories of the United Kingdom.

For Objective 4(b): New data collection on imports, production, prices, and current tax levels of tobacco and alcohol products in three CARICOM countries, and modeling the potential effects of tax rises on sales and tax revenue.

For Objective 4(c): In-depth, semistructured, qualitative interviews with regional and national stakeholders involved in organizing and implementing Caribbean Wellness Day, and analysis of media penetration.

For Objective 5 and Objective 6: In-depth semistructured interviews with stakeholders in key regional and international organizations, including $\mathrm{PAHO}$, CARPHA, UWI, and WHO.

\section{Ethical considerations}

The evaluation received approval from the Institutional Review Board of the University of the West Indies, Cave Hill Campus (Barbados), plus appropriate approval from each of the countries in which new data collection took place.

\section{RESULTS}

The subsections below highlight three broad areas of findings and provide an introduction to the more detailed papers in the rest of this supplement.

\section{Disparities in trends in mortality}

There are marked disparities in NCD mortality and in trends in NCD mortality over time among the CARICOM members. Major contributors to these disparities are trends in cardiovascular disease (CVD) (stroke and ischemic heart disease) and diabetes mellitus

TABLE 2. Percentage decline in age-adjusted premature ( $<70$ years old) cardiovascular disease and diabetes mellitus mortality for women and men in Caribbean Community countries with available data for 2001-2005 and 2006-2011 a

\begin{tabular}{lrll}
\hline \multicolumn{1}{c}{ 2001-2005 } & \multicolumn{3}{c}{ 2006-2011 } \\
\hline Women & 24.1 & Women & \\
Trinidad \& Tobago & 15.5 & Saint Lucia & 27.1 \\
Jamaica & 15.2 & Barbados & 24.5 \\
Bahamas & 14.6 & Suriname & 15.9 \\
Guyana & 13.5 & St. Vincent \& Grenadines & 14.8 \\
Suriname & 6.8 & Belize & 13.9 \\
Saint Lucia & 4.3 & Trinidad \& Tobago & 13.0 \\
St. Vincent \& Grenadines & 0.6 & Bahamas & 9.5 \\
Grenada & -3.1 & Guyana & 6.9 \\
Antigua \& Barbuda & -4.9 & Jamaica & 6.0 \\
Barbados & -6.1 & Antigua \& Barbuda & 2.6 \\
Belize & & Grenada & -4.3 \\
Men & 26.0 & Men & 23.8 \\
Belize & 20.2 & Barbados & 20.9 \\
Trinidad \& Tobago & 11.1 & Saint Lucia & 12.0 \\
Antigua \& Barbuda & 6.3 & Trinidad \& Tobago & 9.7 \\
St. Vincent \& Grenadines & 5.3 & Bahamas & 9.1 \\
Bahamas & 2.7 & Suriname & 3.1 \\
Suriname & 1.8 & Belize & 2.3 \\
Jamaica & 0.5 & Guyana & -2.3 \\
Guyana & -6.0 & Jamaica & -3.6 \\
Grenada & -6.1 & Grenada & -8.5 \\
Barbados & -27.1 & Antigua \& Barbuda & -9.4 \\
Saint Lucia & & St. Vincent \& Grenadines & \\
\hline
\end{tabular}

Source: Paper by Razavi et al. (17).

${ }^{a}$ In the respective cells, dark green shading indicates a decline in mortality $>20 \%$; light green shading indicates a decline in mortality of $10 \%-20 \%$; pink shading indicates an increase in mortality of $0 \%-20 \%$; and red shading indicates an increase in mortality $>20 \%$.

(DM) mortality (combined as CVD-DM mortality). Table 2 shows the marked differences in premature $(<70$ years $)$ CVD-DM mortality trends among CARICOM countries with available data from the WHO Mortality Database and UN population figures. Further detail is given in the paper by Razavi et al. (17) in this supplement.

\section{Barriers and facilitators to country implementation of the 2007 Port- of-Spain Declaration}

Among the CARICOM members, there are widely differing levels of policy development and implementation in response to the 2007 Port-of-Spain Declaration. The number of indicators met, as reported by each CARICOM member in 2014 in the monitoring grid, is shown in Table 3.

No CARICOM member had implemented all the mandates from the 2007 Declaration, as monitored by the 26 indicators, and with 10 members implementing fewer than half of the mandates. There was a clear relationship between country population size and the number of mandates implemented (Figure 1), with the main outlier in this relationship being Haiti, the poorest country in CARICOM. Barbados and the Cayman Islands performed better than would be predicted by their population size.

Across the 20 CARICOM countries, those mandates that had the best implementation tended to be those for which there was support from regional organizations. These included Caribbean Wellness Day, risk factor surveillance, and ratification of the Framework Convention on Tobacco Control (FCTC). For Caribbean Wellness Day, this assistance included planning supports, provision of branding materials, and a tool kit from PAHO (27). Risk factor surveillance was reinforced by technical support from CARPHA personnel. FCTC support came through the clear road map provided by the FCTC and help from PAHO. 
TABLE 3. Caribbean Community (CARICOM) members by gross domestic product per capita, population, and number of CARICOM 2007 Port-of-Spain Declaration indicators met in 2014

\begin{tabular}{|c|c|c|c|}
\hline Level of compliance/Member & GDP per capita PPP $\$^{\mathrm{a}}$ & $\begin{array}{l}\text { Population } \\
\text { (thousand) }^{b}\end{array}$ & $\begin{array}{c}\text { Number of indicators } \\
\text { met (out of } 26 \text { ) }\end{array}$ \\
\hline \multicolumn{4}{|l|}{ Highest compliers } \\
\hline Barbados & 17235 & 283 & 20 \\
\hline Trinidad and Tobago & 33284 & 1354 & 19 \\
\hline Jamaica & 8482 & 2862 & 18 \\
\hline Bahamas & 23191 & 382 & 17 \\
\hline \multicolumn{4}{|l|}{ Middle compliers } \\
\hline Grenada & 12682 & 106 & 15 \\
\hline Cayman Islands & $\begin{array}{c}43800^{c} \\
\text { (2004 est.) }\end{array}$ & 59 & 15 \\
\hline Guyana & 7280 & 763 & 15 \\
\hline Saint Lucia & 12398 & 176 & 15 \\
\hline Suriname & 16125 & 548 & 14 \\
\hline Antigua & 20620 & 99 & 14 \\
\hline Bermuda & $\begin{array}{c}85700^{c} \\
\text { (2013 est.) }\end{array}$ & $64^{d}$ & 12 \\
\hline British Virgin Islands & $\begin{array}{c}42300^{c} \\
\text { (2010 est.) }\end{array}$ & 30 & 11 \\
\hline Dominica & 10803 & 73 & 11 \\
\hline Belize & 8433 & 352 & 9 \\
\hline Saint Kitts and Nevis & 24738 & 54 & 8 \\
\hline Saint Vincent and the Grenadines & 10867 & 109 & 7 \\
\hline \multicolumn{4}{|l|}{ Lowest compliers } \\
\hline Anguilla & $\begin{array}{c}12200^{c} \\
\text { (2008 est.) }\end{array}$ & 14 & 5 \\
\hline Turks and Caicos & $\begin{array}{c}29100^{c} \\
\text { (2007 est.) }\end{array}$ & 34 & 2 \\
\hline Montserrat & $\begin{array}{c}8500^{c} \\
\text { (2006 est.) }\end{array}$ & 5 & 2 \\
\hline Haiti & 1741 & 10572 & 1 \\
\hline
\end{tabular}

Source: Unless indicated otherwise (see footnotes that follow), the data on the population size are from United Nations Population Division and the data on gross domestic product are from the World Bank.

a Unless indicated otherwise, these data on gross domestic product (GDP) per capita (at purchasing power parity (PPP)) are from the World Bank.

${ }^{b}$ Unless indicated otherwise, these data on population size are from United Nations Population Division.

c These GDP data are from the U.S. Central Intelligence Agency (www.cia.gov/library/publications/the-world-factbook/ fields/2004.html).

${ }^{d}$ The population figure for Bermuda is from the country's 2010 census.

Table 4 lists the indicators by level of implementation (percent of the indicator fully or partially met) among the 20 CARICOM members, alongside the regional and international organizations that provide support for their implementation. The least well implemented indicators tended to be those with the least support from regional and international organizations, and include some of the macro-determinants of diet and physical activity. While 15 of the CARICOM countries and territories reported that they had convened an NCD Commission (which is recommended as the mechanism for engaging all of society in addressing the multifactorial upstream determinants of health), these commissions or analogous bodies were reported to be functioning in only 10 of those 15, according to a report prepared by the Healthy Caribbean Coalition (https://www.healthycaribbean.org/wp-content/uploads / 2016/ 04/A-Civil-Society-Report-on-NationalNCD-Commissions-in-the-CaribbeanTowards-a-more-Effective-MultisectoralResponse-to-NCDs-Part-1.pdf).

\section{Investing in NCD prevention and control: potential role of tobacco and alcohol taxes}

Revenue generated from further increasing taxes on tobacco and alcohol could exceed US\$ 37 million in Grenada, Jamaica, and Trinidad and Tobago
(20). That amount is three times the estimated US\$ 12.6 million cost of World Health Organization "best buy" NCD interventions for these populations. With increased taxes on tobacco and alcohol, consumption will fall $(28,29)$ since the price elasticity assumptions used are all negative. The methods and findings from those three CARICOM countries are reported in detail in the paper by La Foucade et al. (20) in this supplement.

\section{DISCUSSION}

The overall objective of the evaluation of 2007 Port-of-Spain Declaration on NCDs was to assess implementation of its mandates, learn lessons, and, through the dissemination of the findings, help accelerate further implementation. This paper provides an introduction to the detailed objectives, the methods used, and some of the main findings. Other papers in this supplement provide details on the methods and findings for specific objectives (Box 1).

From our introduction to the evaluation, there are four noteworthy, broad conclusions. The first is that there are marked disparities in both rates and trends in premature NCD mortality among CARICOM members (30-33). This is summarized in Table 2 and discussed in greater detail in the paper by Razavi et al. (17) in this supplement. There is no clear-cut relationship between the degree of implementation in the Port-of-Spain commitments as assessed by the monitoring grid and in the change in CVD-DM mortality. Two of the countries that performed best on implementation (Barbados and Trinidad and Tobago) did have large declines in mortality after 2007. However, Saint Lucia and Saint Vincent and the Grenadines also had large decreases in mortality, but they performed much less well, according to the monitoring grid results. The grid scores provide a high-level assessment of implementation, and they also indicate the need for more specific hypothesis-driven investigation into what underlies these differences. One such investigation has been conducted in Barbados for trends in coronary heart disease mortality, and it found that improved coverage of effective medical treatments could largely explain the decline in mortality, despite a background of worsening risk factors (34). 
FIGURE 1. Country percentage of compliance with Caribbean Community 2007 Port-of-Spain Declaration mandates in 2014 vs. country population size (log scale)

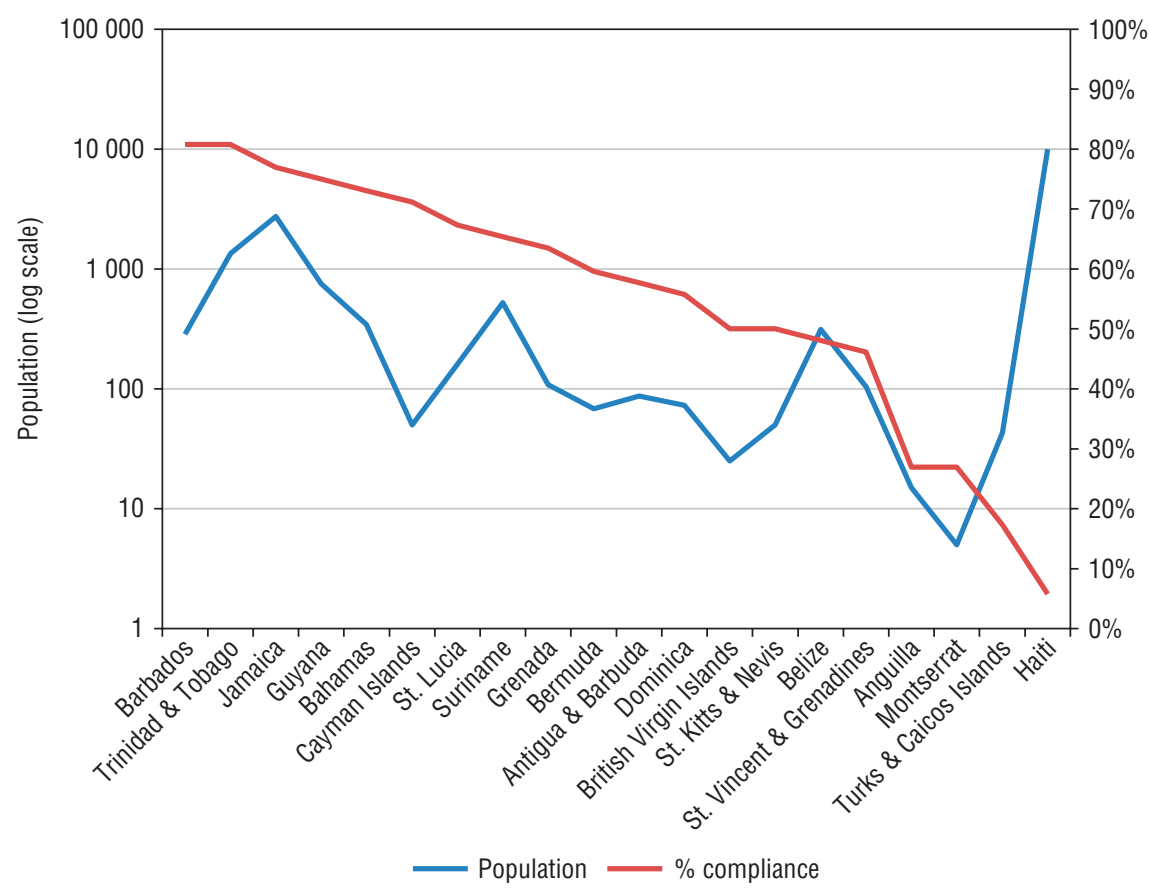

Source: Author T.A. Samuels.
A weakness of the mortality analyses presented here is that they only run to 2011, and trends beyond this time point may be different. A further weakness is that the analyses do not include countries with populations of fewer than 90000 (true for 8 of the 20 CARICOM members), as population denominator data for them was not readily available. The Global Burden of Disease Study does provide estimates of mortality rates for these 8 countries, but as others have done elsewhere $(30,31)$, we have chosen to focus on original rather than modeled data.

A second broad conclusion is that countries with additional capacity, as indicated by greater population size, were able to implement more of the Declaration's mandates. The major exception to this was Haiti, the largest country in CARICOM but the one with the lowest level of implementation. In Haiti, lack of capacity is undoubtedly also related to its extreme poverty, being the poorest country in the Americas and the only one

TABLE 4. Percentage of Caribbean Community (CARICOM) 2007 Port-of-Spain Declaration grid indicator compliance among the 20 CARICOM members, with associated regional and international organizational support, based on grid reports received by the University of the West Indies in $2015^{a}$

\begin{tabular}{|c|c|c|}
\hline Indicator & Regional/international organizations supporting & 2015 score \\
\hline FCTC ratified & WHO FCTC, PAHO & $95 \%$ \\
\hline NCD plan & PAHO/WHO, CARICOM, HCC & $85 \%$ \\
\hline Global School Health Survey & PAHO/WHO, CDC & $83 \%$ \\
\hline Ongoing, mass physical activity (PA) or new public PA spaces & $\ldots$ & $80 \%$ \\
\hline STEPS or equivalent survey & PAHO/WHO, CARPHA & $75 \%$ \\
\hline Smoke-free indoor public places & WHO FCTC, PAHO, Bloomberg philanthropies project & $65 \%$ \\
\hline Multi-sector food \& nutrition plan implemented & PAHO/WHO & $65 \%$ \\
\hline QOC CVD or diabetes demonstration project & PAHO/WHO & $65 \%$ \\
\hline Multi-sectoral NCD Commission appointed and functional & CARICOM, HCC & $63 \%$ \\
\hline Mandatory physical activity in all grades in schools & $\ldots$ & $63 \%$ \\
\hline NCD budget & $\ldots$ & $58 \%$ \\
\hline Tobacco taxes $>50 \%$ sale price & WHO FCTC, PAHO & $45 \%$ \\
\hline Advertising, promotion, \& sponsorship bans on tobacco & WHO FCTC, PAHO & $38 \%$ \\
\hline$\geq 50 \%$ of public and private institutions with physical activity and healthy eating programs & $\ldots$ & $33 \%$ \\
\hline Mandatory provision for PA in new housing developments & $\ldots$ & $23 \%$ \\
\hline Mandatory labeling of packaged foods for nutrition content & $\ldots$ & $18 \%$ \\
\hline Trade agreements utilized to meet national food security \& health goals & $\ldots$ & $13 \%$ \\
\hline Trans fat free food supply & $\ldots$ & $8 \%$ \\
\hline
\end{tabular}

Source: Author T.A. Samuels.

${ }^{a}$ The abbreviations and the symbol used in the table are: CARPHA = Caribbean Public Health Agency; $C D C=($ U.S. $)$ Centers for Disease Control and Prevention; $C V D=$ cardiovascular disease; CWD = Caribbean Wellness Day; FCTC = Framework Convention on Tobacco Control; HCC = Healthy Caribbean Coalition; NCD = noncommunicable disease; $\mathrm{PA}=$ physical activity; $\mathrm{PAHO}=$ Pan American Health Organization; $\mathrm{PHC}=$ primary health care; $\mathrm{QOC}=$ quality of care; $\mathrm{WHO}=$ World Health Organization; $\ldots=$ no support from regional organizations. 
in which the burden of disease and mortality from infectious causes is still greater than from NCDs $(1,2)$.

A third conclusion is that in addition to national capacity, support to national governments from regional and international organizations has played a very important role in enhancing the implementation of some mandates (35). Those mandates for which there exists guidance and support appear to have been the best implemented. This type of support is likely to be particularly important for those smaller countries with the least capacity for developing and implementing policy. This relationship is explored further in two papers in this supplement, by Murphy et al. (19) and by Kirton et al. (22).

Fourth, there is much room to improve "all of society" and "all of government" responses to NCDs, both at the national and regional levels, taking into account the Health in All Policies model (35-38). The mandate in the 2007 Port-of-Spain Declaration intended to promote an "all of society" response was the establishment of national NCD Commissions or analogous bodies. However, these commissions were reported as being functional in only half the CARICOM countries. In smaller countries, with limited human resources, having one NCD Commission that supports multisectorality for health and wellness can be more feasible than one focused on specific disease groups. However, NCD Commissions do not address the need for "all of government" responses, which require the establishment of mechanisms to facilitate cross-sectoral working within government in order to achieve the oft-stated public health goal of Health in All Policies. One recommendation has been for an interministerial task force on NCDs. However, there would still be the need for political capital to be invested in convincing government ministers other than the health minister that priority for actions in their ministries should include addressing NCD risk factors. Health in All Policies remains a concept that has yet to be institutionalized. These issues are addressed in the paper in this supplement by Murphy et al. (19).

In conclusion, the evaluation of the 2007 CARICOM Port-of-Spain
Declaration on NCDs was intended to learn lessons and inform further implementation. Approaches to dissemination are reviewed in the paper in this supplement by Greaves et al. (25). A major vehicle for dissemination has been the construction of a custom-built website (www.onecaribbeanhealth.org) and the use of social media.

The main results of the evaluation were considered at a multisectoral stakeholder workshop held in Portof-Spain in February 2016. At this workshop, multisectoral and multidisciplinary groups were established to draft recommendations for action. Detailed recommendations from these groups are available on the evaluation project's website (https:/ / onecaribbeanhealth. org/).

A core set of recommendations were presented to the regular CARICOM Heads of Government meeting in July $2016{\text { (the } 37^{\text {th }}}$ regular meeting) and July 2017 (the $38^{\text {th }}$ regular meeting). The recommendations emphasized the relative lack of multisectoral action on the upstream determinants of NCDs, particularly ones related to diet and physical activity. The recommendations also reflected the fact that although 13 out of the 14 independent CARICOM countries had ratified the Framework Convention on Tobacco Control, there was much less evidence that its articles (including banning smoking in public places) had been fully implemented.

In response to these recommendations, the CARICOM Heads of Government meetings issued a communique on NCDs in 2016 and again in 2017. The full text of the two communiques is available on the CARICOM website (https: / / caricom.org/media-center / communications/communiques/). In brief, the communiques reinforce the commitments of the CARICOM Heads of Government to taking multisectoral action to address the determinants of NCDs. Actions referred to include banning smoking in public places; supporting increased domestic food production; using fiscal and legislative measures to promote the consumption of nutritious foods and decrease the consumption of those high in added sugar, salt, and trans fats; and banning advertising to children of highly processed foods.
Based on the evidence from this evaluation, the major challenge and opportunity for accelerating action on NCDs is to take advantage of the political momentum represented by the mandates from the 2016 and 2017 CARICOM Heads of Government communiques. Further development and collaborative deployment of regional public goods (such as tool kits and model legislation) for NCD policies and programs will be essential.

Author contributions. T. Alafia Samuels and Nigel Unwin conceived the original idea, planned the research project, interpreted the results, wrote the paper, reviewed the paper, and approved the final version.

Acknowledgments. The names and affiliations of the investigators for the evaluation were: University of the West Indies (UWI), Barbados: L. Bartholomew, L. Bishop, M. Murphy, T.A. Samuels (Principal Investigator), N. Unwin (CoPrincipal Investigator); UWI, Mona campus, Jamaica (Department of Community Health and Psychiatry): A. Bailey, G. Leveridge, M. Harris; UWI, St. Augustine campus, Trinidad and Tobago (Centre for Health Economics): S. Gabriel, A. La Foucade, C. Metivier, K. Theodore; UWI, St. Augustine campus, Trinidad and Tobago (Institute of International Relations): D. Hippolyte, A. Knight; UWI (Chancellors Office): G. Alleyne; University of Toronto (G8 Research Group): C. Bracht, J. Kirton, M. Koch, J. Kulik; Caribbean Public Health Agency: G. Andall-Bereton, C. Bocage, R. Franklin-Peroune, A. Hinds, Y. Holder, J. Hospedales, M. Ivey, E. Lloyd; Healthy Caribbean Coalition: T. Hassell, M. Hutton, J. Tull; PAHO (Eastern Caribbean Office): C. BoydScobie, B. Irons, T. Kanda, G. Xuereb; CARICOM Secretariat: R. Cummings. (Full details on the evaluation investigators are available in the document titled The Evaluation of the 2007 CARICOM Heads of Government Port of Spain NCD Summit Declaration, which is available at: http:/ / onecaribbeanhealth. org/wp-content/uploads / 2018/01/ POSDEVAL_The-Investigators-report_ FINAL.pdf).

In addition, the following individuals are thanked for contributing as members of the International and Regional 
Advisory Committee: G. Alleyne (PAHO) R. Brownson (Washington University in St. Louis); A. Hennis (PAHO); V. Narayan (Emory University); R. Nugent (University of Washington); R. Rodin (Public Health Agency of Canada); D. Stuckler (University of Oxford); T. Davidson (Ministry of Health, Jamaica);
Y. Lewis (Ministry of Health, Trinidad and Tobago); P. Ricketts (Ministry of Health, Commonwealth of Dominica).

\section{Conflicts of interest. None declared.}

Funding. This work was carried out with the aid of a grant from the
International Development Research Centre, Ottawa, Canada.

Disclaimer. Authors hold sole responsibility for the views expressed in the manuscript, which may not necessarily reflect the opinion or policy of the RPSP/ PAJPH or PAHO.

\section{REFERENCES}

1. Pan American Health Organization. Health situation in the Americas: basic indicators 2012. Washington, D.C.: PAHO; 2012.

2. Pan American Health Organization. Health in the Americas, 2017 edition. Available from https://www.paho.org/ salud-en-las-americas-2017/ Accessed on 18 November 2018.

3. Samuels TA, Guell C, Legetic B, Unwin N. Policy initiatives, culture and the prevention and control of chronic non-communicable diseases (NCDs) in the Caribbean. Ethn Health. 2012;17(6):631-49.

4. Gakidou E, Afshin A, Abajobir AA, Abate $\mathrm{KH}$, Abbafati C, Abbas KM, et al. Global, regional, and national comparative risk assessment of 84 behavioural, environmental and occupational, and metabolic risks or clusters of risks, 1990-2016: a systematic analysis for the Global Burden of Disease Study 2016. Lancet. 2017 Sep 16;390(10100):1345-422.

5. Sobers-Grannum N, Murphy MM, Nielsen A, Guell C, Samuels TA, Bishop L, et al. The importance of gender as a social determinant of diabetes in the Caribbean: a systematic review and meta-analysis. PLoS One. 2015 May 21;10(5):e0126799. doi: 10.1371/journal.pone.0126799. eCollection 2015.

6. Ng M, Fleming T, Robinson M, Thomson B, Graetz N, Margono C, et al. Global, regional, and national prevalence of overweight and obesity in children and adults during 1980-2013: a systematic analysis for the Global Burden of Disease Study 2013. Lancet. 2014 Aug 30;384(9945):766-81. doi: 10.1016/S0140-6736(14)60460-8.

7. Irons B, Smith HC, Carrasco PA, De Quadros C. The immunisation programme in the Caribbean. Caribb Health. 1999;2(3):9-11.

8. Irons B, Dobbins JG. The Caribbean experience in maintaining high measles vaccine coverage. J Infect Dis. 2011;204 Suppl 1:S284-8.

9. Rivera-Andrade A, Luna MA. Trends and heterogeneity of cardiovascular disease and risk factors across Latin American and Caribbean countries. Prog Cardiovasc Dis. 2014;57(3):276-85.

10. Hospedales CJ, Samuels TA, Cummings R, Gollop G, Greene E. Raising the priority of chronic noncommunicable diseases in the Caribbean. Rev Panam Salud Publica. 2011 Oct;30(4):393-400.
11. Eldemire-Shearer D, James K, Morris C, Holder-Nevins D, Lawes $H$, Harris $M$ Chronic disease and ageing in the Caribbean: opportunities knock at the door. West Indian Med J. 2011;60(4):471-7.

12. Samuels TA, Hospedales CJ. From Portof-Spain summit to United Nations High Level Meeting: CARICOM and the global non-communicable disease agenda. West Indian Med J. 2011;60(4):387-91.

13. Ordunez P, Prieto-Lara E, Pinheiro Gawryszewski V, Hennis AJ, Cooper RS. Premature mortality from cardiovascular disease in the Americas - Will the goal of a decline of " $25 \%$ by 2025 " be met? PLoS One. 2015;10(10):e0141685.

14. Caribbean Community Secretariat. CARICOM Heads adopt declaration on NCDs. Available from: http://www.caricom.org/jsp/pressreleases/pres212_07. jsp Accessed on 18 November 2018.

15. Samuels TA, Kirton J, Guebert J. Monitoring compliance with high-level commitments in health: the case of the CARICOM Summit on Chronic NonCommunicable Diseases. Bull World Health Organ 2014;92(4):270-6b.

16. Samuels TA, Murphy MM, Unwin N. Validating the self-reported annual monitoring grid for the 2007 Caribbean Community Declaration of Port-ofSpain on noncommunicable diseases. Rev Panam Salud Publica. 2018;42:e189. https:/ / doi.org/10.26633/RPSP.2018.189

17. Razavi A, Hambleton I, Samuels TA, Sobers N, Unwin N. Premature mortality from cardiovascular disease and diabetes in the Caribbean and associations with health care expenditure, 2001-2011. Rev Panam Salud Publica. 2018;42:e179. https:/ /doi.org/10.26633/RPSP.2018.179

18. Guariguata L, Brown C, Sobers N, Hambleton I, Samuels TA, Unwin N. An updated systematic review and meta-analysis on the social determinants of diabetes and related risk factors in the Caribbean. Rev Panam Salud Publica. 2018;42:e171. https://doi.org/10.26633/ RPSP.2018.171

19. Murphy MM, Unwin N, Samuels TA, Hassell TA, Bishop L, Guell C. Evaluating policy responses to noncommunicable diseases in seven Caribbean countries: challenges to addressing unhealthy diets and physical inactivity. Rev Panam Salud Publica. 2018;42:e174. https://doi. org/10.26633/RPSP.2018.174.
20. La Foucade A, Metivier C, Gabriel S, Scott E, Theodore K, Laptiste C. The potential for using alcohol and tobacco taxes to fund prevention and control of noncommunicable diseases in Caribbean Community countries. Rev Panam Salud Publica. 2018;42:e192. https://doi. org/10.26633/RPSP.2018.192

21. Bartholomew L, Bishop L, Brown CR, Murphy MM, Samuels TA. Caribbean Wellness Day: promoting a region-wide day of action. Rev Panam Salud Publica. 2018;42:e105. https://doi.org/10.26633/ RPSP.2018.105.

22. Kirton J, Knight WA, Hospedales CJ, Hippolyte D, Kulik J. Regional and global impacts of the 2007 Port-ofSpain Declaration on noncommunicable diseases. Rev Panam Salud Publica. 2018;42:e194. https://doi.org/10.26633/ RPSP.2018.194.

23. Haynes E, Brown C, Wou C, Vogliano C, Guell C, Unwin N. The Community Food and Health Project. Health and other impacts of community food production in Small Island Developing States: a systematic scoping review. Rev Panam Salud Publica. 2018;42:e176. https://doi. org/10.26633/RPSP.2018.176.

24. Foster N, Thow AM, Unwin N,AlvaradoM, Samuels TA. Regulatory measures to fight obesity in Small Island Developing States of the Caribbean and Pacific. Rev Panam Salud Publica. 2018;42:e191. https://doi. org/10.26633/RPSP.2018.191.

25. Greaves NS, Tull J, Hassell T, Samuels TA. Communication strategy to disseminate the results of the evaluation of the Portof-Spain Declaration (POSDEVAL) across multiple audiences in the Caribbean. Rev Panam Salud Publica. 2018;42:e186 https://doi.org/10.26633/RPSP.2018.186.

26. The Port of Spain Evaluation Research Group. The evaluation of the 2007 CARICOM Heads of Government Port of Spain NCD Summit Declaration. Bridgetown, Barbados: The University of the West Indies; 2017.

27. Samuels TA, Fraser H. Caribbean Wellness Day: mobilizing a region for chronic noncommunicable disease prevention and control. Rev Panam Salud Publica. 2010;28(6):472-9.

28. Wright A, Smith KE, Hellowell M. Policy lessons from health taxes: a systematic review of empirical studies. BMC Public Health. 2017;17(1):583. 
29. Blecher E. Taxes on tobacco, alcohol and sugar sweetened beverages: linkages and lessons learned. Soc Sci Med. 2015 Jul;136-137:175-9. doi: 10.1016/j. socscimed.2015.05.022.

30. Hambleton IR, Jeyaseelan S, Howitt C, Sobers-Grannum N, Hennis AJ, Wilks RJ, et al. Cause-of-death disparities in the African diaspora: exploring differences among shared-heritage populations. Am J Public Health. 2015;105 Suppl 3:S491-8.

31. Hambleton IR, Howitt C, Jeyaseelan S, Murphy MM, Hennis J, Wilks R, et al. Trends in longevity in the Americas: disparities in life expectancy in women and men, 1965-2010. PLoS One. 2015;10(6):e0129778.

32. Brown CR, Hambleton IR, Hercules SM, Alvarado M, Unwin N, Murphy MM, et al. Social determinants of breast cancer in the Caribbean: a systematic review. Int J Equity Health. 2017;16(1):60.

33. Bidulescu A, Ferguson TS, Hambleton I, Younger-Coleman N, Francis D, Bennett N, et al. Educational health disparities in hypertension and diabetes mellitus among African descent populations in the Caribbean and the USA: a comparative analysis from the Spanish town cohort (Jamaica) and the Jackson heart study (USA). Int J Equity Health. 2017;16(1):33.

34. Sobers-Grannum, Samuels TA, Rose AMC Capewell S, O'Flaherty M, Unwin N. Explaining the trends in coronary heart disease mortality in Barbados: 19902012. West Indian Med J. 2016;65(Supp 3):1-79.

35. Unwin N, Samuels TA, Hassell T, Brownson RC, Guell C. The development of public policies to address non-communicable diseases in the Caribbean country of Barbados: the importance of problem framing and policy entrepreneurs. Int J Health Policy Manag. 2016;6(2):71-82.

36. Van Vliet-Brown CE, Shahram S, Oelke ND. Health in All Policies utilization by municipal governments: scoping review. Health Promot Int. 2018 Aug 1;33(4):71322. doi: $10.1093 /$ heapro/dax008.

37. Shankardass K, Muntaner C, Kokkinen L, Shahidi FV, Freiler A, Oneka G, et al. The implementation of Health in All Policies initiatives: a systems framework for government action. Health Res Policy Syst. 2018;16(1):26.

38. de Leeuw E. Engagement of sectors other than health in integrated health governance, policy, and action. Annu Rev Public Health. 2017;38:329-49.

Manuscript received on 10 June 2018. Revised version accepted for publication on 26 September 2018.
RESUMEN

\section{La Declaración de Puerto España sobre enfermedades no transmisibles de 2007: panorama general de una evaluación multidisciplinaria}

\author{
Palabras clave
}

Objetivos. Las enfermedades no transmisibles (ENT) son una amenaza para el desarrollo social y económico, incluso en el Caribe. En 2007, la Comunidad del Caribe (CARICOM) celebró la primera cumbre mundial de jefes de gobierno sobre prevención y control de las ENT y emitió la histórica Declaración de Puerto España: Unidos para detener la epidemia de ENT crónicas. Los objetivos de este documento son proporcionar un panorama general de la evaluación formal de la Declaración y destacar los hallazgos clave de esta, que aportan información para implementar adicionalmente los 15 mandatos de esta Declaración.

Métodos. Los seis objetivos de la evaluación se decidieron a través de la participación de las partes interesadas y se evaluaron mediante métodos de investigación cuantitativos y cualitativos concurrentes, utilizando los siguientes temas: 1) tendencias en los factores de riesgo, la morbilidad y la mortalidad; 2) respuestas políticas nacionales y del Caribe en conjunto y factores asociados con los éxitos y dificultades de las políticas; 3) impacto internacional de la Declaración; y 4) potencial para aumentar los ingresos públicos por impuestos al tabaco y el alcohol para apoyar la prevención y el control de las ENT.

Resultados. Existen marcadas disparidades en la mortalidad por ENT y sus tendencias entre los 20 países y territorios miembros de la CARICOM. Ningún miembro de la CARICOM ha implementado completamente los 15 mandatos de la Declaración (que fueron monitoreados por 26 indicadores); 10 miembros de la CARICOM han implementado menos de la mitad de los indicadores, y la mayoría de los miembros carecen de una Comisión multisectorial de ENT que funcione adecuadamente. Los Estados Miembros de la CARICOM más grandes tienden a tener niveles más altos de implementación que los más pequeños. Los mandatos que recibieron apoyo activo de instituciones regionales tendieron a ser mejor implementados por los miembros de la CARICOM que los mandatos que carecen de ese tipo de apoyo. Los aumentos factibles de los impuestos nacionales al tabaco y al alcohol podrían cubrir con creces el costo de implementar las intervenciones consideradas las "mejores inversiones" contra las ENT según la Organización Mundial de la Salud en los países y territorios miembros de la CARICOM. Conclusiones. Las prioridades para ampliar la implementación de los mandatos de la Declaración de Puerto España incluyen el establecimiento en todos los países miembros y territorios de la CARICOM de organismos nacionales que funcionen plenamente para apoyar la acción multisectorial que conlleve a la prevención de las ENT; mayor apoyo regional en el desarrollo de políticas y su implementación en los países más pequeños; y aumentar el uso de los impuestos al tabaco y el alcohol para apoyar el control y la prevención de las ENT.

Enfermedades no transmisibles; medicina preventiva; política de salud; proyectos de investigación; diagnóstico de la situación de salud; Región del Caribe. 
RESUMO

\section{A Declaração de Porto Espanha sobre doenças não transmissíveis de 2007: panorama geral de uma avaliação multidisciplinar}

Objetivos. As doenças não transmissíveis (DNT) são uma ameaça ao desenvolvimento social e econômico, inclusive no Caribe. Em 2007, a Comunidade do Caribe (CARICOM) realizou a primeira cúpula global de chefes de governo sobre prevenção e controle das DNT e publicou a histórica Declaração de Porto Espanha: Unidos para deter a epidemia de DNT crônicas. Os objetivos deste documento são fornecer um panorama geral da avaliação formal da Declaração e destacar suas principais conclusões, que fornecem informações sobre a implementação dos 15 mandatos desta Declaração.

Métodos. Os seis objetivos da avaliação foram decididos por meio da participação das partes interessadas e avaliados por métodos de pesquisa simultânea quantitativa e qualitativa, utilizando os seguintes temas: 1) tendências nos fatores de risco, morbidade e mortalidade; 2) respostas políticas nacionais e do Caribe e fatores associados aos sucessos e dificuldades das políticas; 3) impacto internacional da Declaração; e 4) potencial para aumentar a renda do imposto sobre o tabaco e o álcool para apoiar a prevenção e o controle das DNT.

Resultados. Existem disparidades na mortalidade e nas tendências das DNT entre os 20 países e territórios membros da CARICOM. Nenhum membro da CARICOM havia implementado integralmente os 15 mandatos da Declaração (que foram monitorados por 26 indicadores); 10 membros da CARICOM haviam implementado menos da metade dos indicadores e a maioria dos membros não tinha uma comissão multissetorial das DNT que funcionar corretamente. Os Estados Membros maiores da CARICOM tendem a ter níveis mais altos de implementação do que os membros menores. Os mandatos que receberam apoio ativo de instituições regionais tendem a ser melhor implementados pelos membros da CARICOM do que os que faltam esse tipo de apoio. Os possíveis aumentos nos impostos nacionais sobre tabaco e álcool poderiam mais do que cobrir o custo de implementar as intervenções de "melhores investimentos" contra DNT da Organização Mundial de Saúde nos países e territórios membros da CARICOM.

Conclusões. As prioridades para expandir a implementação dos mandatos da Declaração de Porto Espanha incluem o estabelecimento em todos os países e territórios membros da CARICOM de agências nacionais que funcionem plenamente para apoiar ações multissetoriais de prevenção de DNT; maior apoio regional no desenvolvimento de políticas e sua implementação em países pequenos; e aumentar o uso de impostos sobre tabaco e álcool para apoiar o controle e a prevenção de DNT.

Palavras-chave Doenças não transmissíveis; medicina preventiva; política de saúde; projetos de pesquisa; diagnóstico da situação de saúde; Região do Caribe. 